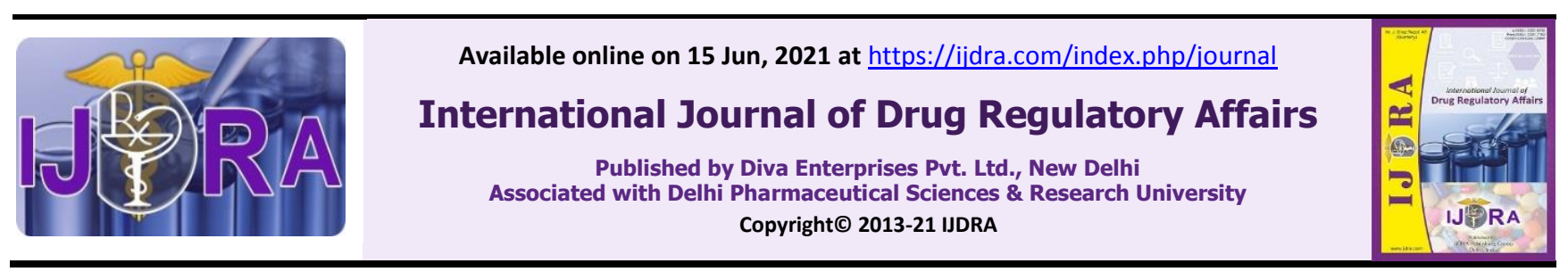

Review Article

\title{
Interview Questions on ANDA filing
}

\section{Rajkumar Gupta*}

Perfect Pharmaceutical Consultants Pvt. Limited, Chinchwad, Pune, India 411019

\section{Abstract}

This guidance document provides prominent facts on ANDA filings in FAQ format. It covers aspects like drafting, submission, review, approval of ANDA in question answer format. It is an excellent database for those seeking appointment in large pharmaceutical companies.

Keywords: Drug Master File (DMF), ANDA, NDA, FDA, CDER, OGD

Article Info: Received 19 Apr. 2021; Review Completed 03 Jun. 2021; Accepted 04 Jun. 2021

Cite this article as:

Gupta R. Interview Questions on ANDA filing. Int J Drug Reg Affairs [Internet]. 2021 Jun 15 [cited 2021 Jun 15]; 9(2):2025. Available from:

http://ijdra.com/index.php/journal/article/view/464

DOI: $10.22270 / i j d r a . v 9 i 2.464$

*Corresponding author

\section{Introduction}

The companies like Dr Reddy, Cipla, Biocon, Alembic, Unichem, and Aurobindo offer high profile job to pharma professionals. These companies are known worldwide for filing large number of ANDA. Hence, if you are seeking job in such companies a sound Table 1. Question Answers on ANDA filing (1-17) knowledge about ANDA is mandatory. This article is designed to train you to face likely questions during interview. Please try to understand the question before answering. The questions are presented at random.

\section{Question Answers on ANDA filing}

\begin{tabular}{|c|c|c|}
\hline $\begin{array}{l}\text { Sr. } \\
\text { No. }\end{array}$ & Question & Answer \\
\hline 1. & What is ANDA? & Authorization to market generic version of New drugs \\
\hline 2. & What is IND? & $\begin{array}{l}\text { Authorization to conduct clinical trials on New Drug } \\
\text { Substance }\end{array}$ \\
\hline 3. & What is NDA? & Authorization to market New Drug Product \\
\hline 4. & What is $\mathrm{ICH} ?$ & $\begin{array}{l}\text { ICH is a joint project of Europe, Japan, United States and } \\
\text { experts from the pharmaceutical industry to harmonize the } \\
\text { quality, safety and efficacy of pharmaceutical product }\end{array}$ \\
\hline 5. & $\begin{array}{l}\text { What are the common Technical features of } \\
\text { NDA and ANDA? }\end{array}$ & $\begin{array}{l}\text { Same dosage form } \\
\text { Same strength } \\
\text { Same contents on the label } \\
\text { Same route of administration } \\
\text { Same indication/dosage } \\
\text { Similar BE pattern }\end{array}$ \\
\hline 6. & $\begin{array}{l}\text { Name the year in which Hatch Watchman Act } \\
\text { was enacted? How it influenced market for } \\
\text { generic drugs? }\end{array}$ & $\begin{array}{l}\text { Hatch Watchman Act was enacted in } 1984 \text {. } \\
\text { It improved the market share of the generic products to the } \\
\text { extent } 90 \%\end{array}$ \\
\hline 7. & What is PAI (Preapproval inspection)? & It is an inspection of site prior to approval of ANDA \\
\hline 8. & Describe the objectives of PAI? & $\begin{array}{l}\text { Suitability of site layout and space } \\
\text { manufacturing/testing/storage } \\
\text { Availability of necessary equipment } \\
\text { Availability of necessary test instruments }\end{array}$ \\
\hline
\end{tabular}




\begin{tabular}{|c|c|c|}
\hline & & $\begin{array}{l}\text { Suitability of Man \& Material } \\
\text { Integrity of key personnel } \\
\text { Integrity of QC/QA Labs } \\
\text { Environmental Protection } \\
\text { Availability and suitability of SOP, QC-QA Manual, SMF, } \\
\text { MMFR,BMR }\end{array}$ \\
\hline 9. & $\begin{array}{l}\text { If Module } 4 \text { and } 5 \text { are applicable to ANDA } \\
\text { filing? }\end{array}$ & $\begin{array}{l}\text { Module } 4 \text { is not applicable } \\
\text { Module } 5 \text { is applicable only with respect to BE studies }\end{array}$ \\
\hline 10. & $\begin{array}{l}\text { If } 6 \text { months of accelerated and long-term } \\
\text { stability data is adequate for ANDA filing? }\end{array}$ & $\begin{array}{l}\text { Yes, provided the applicant signs an undertaking to report the } \\
\text { completed studies before marketing the product. }\end{array}$ \\
\hline 11. & $\begin{array}{l}\text { How the drug substance can be solubilized in } \\
\text { water? }\end{array}$ & $\begin{array}{l}\text { By derivtazation /inclusion in water soluble matrix/ /pH } \\
\text { adjustment/ inclusion of organic solvents }\end{array}$ \\
\hline 12. & $\begin{array}{l}\text { If ANDA for as specific drug covers all its } \\
\text { salts/derivatives /polymorphic/chiral forms } \\
\text { NDA filing? }\end{array}$ & $\begin{array}{l}\text { ANDA for a specific drug covers only the specified salt } \\
\text { form/derivatives/polymorphic forms matching with } \\
\text { corresponding NDA. }\end{array}$ \\
\hline 13. & $\begin{array}{l}\text { Why an independent NDA is required for FDC } \\
\text { of which individual drugs are already under } \\
\text { NDA }\end{array}$ & $\begin{array}{l}\text { The safety and efficacy of FDC may differs from its } \\
\text { individual drug components }\end{array}$ \\
\hline 14. & What is standalone NDA & $\begin{array}{l}\text { NDA for a specific drug for its specific derivative } \\
\text { FDA section } 505(\mathrm{~b})(1) \text { is applicable for such NDA }\end{array}$ \\
\hline 15. & $\begin{array}{l}\text { Name the filing required for the new } \\
\text { derivative/salt of an approved drug }\end{array}$ & The extended NDA \\
\hline 16. & $\begin{array}{l}\text { Name the filing required for marketing new } \\
\text { strength of an approved product }\end{array}$ & The extended NDA \\
\hline 17. & $\begin{array}{l}\text { Name the filing required for marketing two } \\
\text { approved drugs as FDC }\end{array}$ & The extended NDA \\
\hline 18. & $\begin{array}{l}\text { Name the filing required for marketing new } \\
\text { strength of an approved product }\end{array}$ & The extended NDA \\
\hline 19. & $\begin{array}{l}\text { Name the filing required for introducing new } \\
\text { dosage form of an approved drug }\end{array}$ & The extended NDA \\
\hline 20. & $\begin{array}{l}\text { Name the filing required for marketing OTC } \\
\text { drug as prescription drug }\end{array}$ & NDA filing \\
\hline 21. & $\begin{array}{l}\text { Name the filing required for changing the } \\
\text { origin of the drug in an approved drug product } \\
\text { (e.g. natural to synthetic) }\end{array}$ & The extended NDA \\
\hline 22. & $\begin{array}{l}\text { How regulatory applications are aligned for } \\
\text { review by FDA? }\end{array}$ & First in First Review “ \\
\hline 23. & $\begin{array}{l}\text { If cleaning validation data is mandatory in } \\
\text { eCTD? }\end{array}$ & $\begin{array}{l}\text { It may not be a part of filing but FDA can ask it during } \\
\text { inspection }\end{array}$ \\
\hline 24. & $\begin{array}{l}\text { How US DMF (for API/Excipients) is } \\
\text { incorporated in ANDA? }\end{array}$ & It is incorporated by quoting DMF No alloted by FDA. \\
\hline 25. & How CEP is incorporated in ANDA? & It cannot be incorporated in any way \\
\hline 26. & $\begin{array}{l}\text { Specify the format required for ANDA } \\
\text { submission? }\end{array}$ & eCTD \\
\hline 27. & $\begin{array}{l}\text { What is the purpose of "Forced degradation } \\
\text { studies"? }\end{array}$ & $\begin{array}{l}\text { To highlight the } \mathrm{pH} / \text { temperature /environmental conditions by } \\
\text { which the drug gets degraded. }\end{array}$ \\
\hline 28. & What is the purpose of Development History? & $\begin{array}{l}\text { To illustrate that the applicant knows the product } \\
\text { characteristics, stability, storage conditions adequately }\end{array}$ \\
\hline 29. & $\begin{array}{l}\text { How an applicant shall respond to significant } \\
\text { noncompliance or deficiency issued by FDA? }\end{array}$ & $\begin{array}{l}\text { The applicant must explain the probable cause of failure and } \\
\text { must correct it }\end{array}$ \\
\hline 30. & $\begin{array}{l}\text { Why intermediate stability studies shall be } \\
\text { done? }\end{array}$ & $\begin{array}{l}\text { Intermediate stability data is acceptable incase accelerated } \\
\text { data shows deviations }\end{array}$ \\
\hline 31. & $\begin{array}{l}\text { How the drug samples shall be packaged for } \\
\text { stability studies? }\end{array}$ & $\begin{array}{l}\text { They shall be packaged in commercially intended containers- } \\
\text { closures? }\end{array}$ \\
\hline 32. & $\begin{array}{l}\text { How much shelf life can be proposed for a drug } \\
\text { which is stable for } 12 \text { months at ambient } \\
\text { conditions and } 6 \text { months under accelerated } \\
\text { studies? }\end{array}$ & 24 months \\
\hline 33. & $\begin{array}{l}\text { Explain the minimum batch size required for } \\
\text { stability studies of finished products }\end{array}$ & $\begin{array}{l}\text { The batch size shall not be less than } 1 / 10^{\text {th }} \text { of commercial } \\
\text { batch size }\end{array}$ \\
\hline
\end{tabular}




\begin{tabular}{|c|c|c|}
\hline 34. & $\begin{array}{l}\text { If stability data can be expressed in terms of } \\
\text { weeks i.e. } 24 \text { weeks in place of } 6 \text { months }\end{array}$ & No. It need to be expressed only in months \\
\hline 35 . & $\begin{array}{l}\text { If expiry of API can be based on stability } \\
\text { studies performed on Pilot batches }\end{array}$ & $\begin{array}{l}\text { The stability of API must be performed on samples picked up } \\
\text { from commercial batches }\end{array}$ \\
\hline 36. & $\begin{array}{l}\text { If expiry of dosage form can be based on } \\
\text { stability studies performed on Pilot batches }\end{array}$ & Yes. It is accepted by FDA \\
\hline 37. & $\begin{array}{l}\text { State the data required under stability studies of } \\
\text { drug products to be stored at ambient } \\
\text { conditions? }\end{array}$ & $\begin{array}{l}\text { Accelerated stability data over six months } \\
\text { Ambient stability data over alloted expiry date }\end{array}$ \\
\hline 38. & $\begin{array}{l}\text { How the samples of liquid orals, semi-solids, } \\
\text { and suspensions shall be positioned for the } \\
\text { stability studies? }\end{array}$ & $\begin{array}{l}\text { The sample shall be positioned in an inverted, horizontal and } \\
\text { an upright position. }\end{array}$ \\
\hline 39. & $\begin{array}{l}\text { If pilot and commercial batches can differ in } \\
\text { product composition? }\end{array}$ & No \\
\hline 40. & $\begin{array}{l}\text { State the Application fee to be paid under } \\
\text { GUDFA for ANDA filing"? }\end{array}$ & $\begin{array}{l}\text { Initial Application fee FY } 2020 \text { is } \\
\$ 176,237 \text {. }\end{array}$ \\
\hline 41. & What is GUDFA? & Generic Drug User Fees Act. \\
\hline 42. & $\begin{array}{l}\text { If ANDA holders have to pay annual fees to } \\
\text { maintain their filing }\end{array}$ & It is mandatory \\
\hline 43. & What does data exclusivity means? & $\begin{array}{l}\text { The properirory data cannot be copied or incorporated by } \\
\text { reference in any other data. NDA holders have data } \\
\text { exclusivity right for } 5-7 \text { years }\end{array}$ \\
\hline 44. & What does Market Exclusivity means & $\begin{array}{l}\text { Exclusive Marketing rights. } \\
\text { NDA holders have exclusive market right for } 5-7 \text { years }\end{array}$ \\
\hline 45. & $\begin{array}{l}\text { State the Market exclusivity period for "First to } \\
\text { File" ANDA" }\end{array}$ & 6 months \\
\hline 46. & Explain Paeditric Exclusivity & $\begin{array}{l}\text { Exclusive market right for } 6 \text { months } \\
\text { It is granted to NDA holder to conduct paediatric studies } \\
\text { under FDA directives }\end{array}$ \\
\hline 47. & $\begin{array}{l}\text { How the Patent exclusivity (granted by US } \\
\text { PTO) and Market exclusivity granted by FDA } \\
\text { differ from each other? }\end{array}$ & $\begin{array}{l}\text { Patents exclusivity comes into force from the date patent is } \\
\text { filed whereas market exclusivity begins after the drug has } \\
\text { been approved by FDA }\end{array}$ \\
\hline 48. & $\begin{array}{l}\text { State the "Paten exclusivity period "'for New } \\
\text { Drugs }\end{array}$ & 20 years from the date of filing \\
\hline 49. & $\begin{array}{l}\text { State the Market Exclusivity period for New } \\
\text { Drug Products }\end{array}$ & 5 to 7 years \\
\hline 50. & $\begin{array}{l}\text { Explain Market Exclusivity period for the first } \\
\text { to file Generic Drug }\end{array}$ & 6 months \\
\hline 51. & $\begin{array}{l}\text { Can a drug have both Patent and Marketing } \\
\text { exclusivity granted by FDA }\end{array}$ & Yes. \\
\hline 52. & Explain Market Exclusivity period for NCE & $5-7$ years \\
\hline 53. & $\begin{array}{l}\text { Explain Market Exclusivity period for New } \\
\text { Orphan drug }\end{array}$ & 7 years \\
\hline 54. & $\begin{array}{l}\text { What happens when NDA holder files } \\
\text { infringement suit against an ANDA applicant } \\
\text { under para iv? }\end{array}$ & ANDA applicant is put on Hold for 30 moths \\
\hline 55. & $\begin{array}{l}\text { How FDA reacts to falsification of } \\
\text { BA/BE/Clinical data }\end{array}$ & $\begin{array}{l}\text { The falsifier is debarred for participating in BE studies for life } \\
\text { time }\end{array}$ \\
\hline 56. & What is debarment certificate & $\begin{array}{l}\text { It's a declaration stating "We have not employed any } \\
\text { debarred persons in clinical trials/BE studies }\end{array}$ \\
\hline 57. & $\begin{array}{l}\text { How the noncompliance under GMP affects } \\
\text { ANDA certification? }\end{array}$ & $\begin{array}{l}\text { The applicant gets showcase notice and ANDA is kept on } \\
\text { hold until the deficiencies are met }\end{array}$ \\
\hline 58. & Explain the term "Import Alert" & $\begin{array}{l}\text { It's a notification issued to port officials in USA to hold the } \\
\text { shipments of drugs restricted for imports by FDA }\end{array}$ \\
\hline 59. & Explain "Orange Book" & $\begin{array}{l}\text { It is a web based downloadable database published by US } \\
\text { FDA to identify/detail Approved New and Generic Drugs }\end{array}$ \\
\hline 60. & $\begin{array}{l}\text { Name the CTD modules designated to hold } \\
\text { BA/ BE Report }\end{array}$ & Module 5 \\
\hline 61. & What is SPL (Structured Product labelling)? & $\begin{array}{l}\text { It's a structures and well defined format for labelling the } \\
\text { products under ANDA/NDA. }\end{array}$ \\
\hline
\end{tabular}




\begin{tabular}{|c|c|c|}
\hline 62. & $\begin{array}{l}\text { What is the difference in Generics and } \\
\text { Biogenerics? }\end{array}$ & $\begin{array}{l}\text { Generics refer to the synthetic or natural drug under ANDA. } \\
\text { Biogenerics refers to biological drug under ANDA }\end{array}$ \\
\hline 63. & $\begin{array}{l}\text { Name the liquid preparations for which BE } \\
\text { studies are mandatory? }\end{array}$ & Oral suspensions/emulsions for systemic effects \\
\hline 64. & $\begin{array}{l}\text { What is Drug Price Competition and Patent } \\
\text { Term Restoration Act, } 1984 \text { (Hatch-Waxman } \\
\text { Act)? }\end{array}$ & $\begin{array}{l}\text { It's an act to restrict the monopoly of New drugs and to } \\
\text { facilitate launching of their generic version }\end{array}$ \\
\hline 65. & $\begin{array}{l}\text { What is } 180 \text { days exclusivity granted to First } \\
\text { File ANDA? }\end{array}$ & $\begin{array}{l}\text { It's an exclusive marketing right granted to the "first-to-file" } \\
\text { ANDA holder }\end{array}$ \\
\hline 66. & $\begin{array}{l}\text { How confidentiality of critical information in } \\
\text { US DMF is secured by applicant? }\end{array}$ & $\begin{array}{l}\text { The applicant issues specific LOA to restrict review the entire } \\
\text { DMF. }\end{array}$ \\
\hline 67. & $\begin{array}{l}\text { How many vendors can be used for sourcing } \\
\text { API? }\end{array}$ & $\begin{array}{l}\text { Normally, just one vendor is considered adequate. } \\
\text { If API is sourced from two different vendors the development } \\
\text { studies shall be performed using } 3 \text { pilot batched from each } \\
\text { vendor }\end{array}$ \\
\hline 68. & $\begin{array}{l}\text { How many API batches shall be used for the } \\
\text { development of product under ANDA }\end{array}$ & $\begin{array}{l}\text { Minimum tow API batches from the same vendor shall be } \\
\text { used for the product development. }\end{array}$ \\
\hline 69. & What is common mistake in sampling API? & $\begin{array}{l}\text { Sampling 2-3 lots having same batch No in place of sampling } \\
2-3 \text { distinct batches }\end{array}$ \\
\hline 70. & What is the minimum pilot batch size & $\begin{array}{l}1 / 10^{\text {th }} \text { of commercial batch size. } \\
\text { However, in some cases one pilot batch can be less } \\
\text { than } 1 / 10^{\text {th }} \text { of commercial batch }\end{array}$ \\
\hline 71. & $\begin{array}{l}\text { List the variations permitted in labelling of the } \\
\text { products under ANDA }\end{array}$ & $\begin{array}{l}\text { Pack Size and Shape } \\
\text { Color scheme for label }\end{array}$ \\
\hline 72. & $\begin{array}{l}\text { Name the category where variation in } \\
\text { packaging is not allowed }\end{array}$ & The products having fixed treatment cycle \\
\hline 73. & $\begin{array}{l}\text { How many Batch records" are required for } \\
\text { ANDA filing? }\end{array}$ & $\begin{array}{l}\text { Three Executed Pilot scale batch records + One unexecuted } \\
\text { Commercial Scale Batch Record }\end{array}$ \\
\hline 74. & $\begin{array}{l}\text { What is an Exhibit Batch with respect to } \\
\text { ANDA }\end{array}$ & It's a pilot batch marked for BE studies \\
\hline 75. & What are Bio-analytical methods? & $\begin{array}{l}\text { The method used for analyzing the drug from bio samples } \\
\text { such as blood, urine and faecal matter. } \\
\text { It requires validation }\end{array}$ \\
\hline 76. & $\begin{array}{l}\text { Why GUDFA enhances ANDA Review Fees } \\
\text { periodically? }\end{array}$ & To meet the increasing expenses of the agency \\
\hline 77. & Name the functions involved in ANDA filing? & $\begin{array}{l}\text { RLD management } \\
\text { Product Development } \\
\text { Process/Analytical method validation } \\
\text { Stability Studies } \\
\text { Impurity Profiling } \\
\text { BE studies } \\
\text { Label Review } \\
\text { Form 356h } \\
\text { FDA Inspection Management } \\
\text { FDA } 483 \text { resolutions }\end{array}$ \\
\hline 78. & $\begin{array}{l}\text { Explain the CTD Modules applicable/not } \\
\text { applicable for ANDA filing }\end{array}$ & $\begin{array}{l}\text { Module } 1 \text { : Administrative Information } \\
\text { Module } 2 \text { :Overview and summary } \\
\text { Module } 3 \text { : Quality } \\
\text { Please note that } \\
\text { Module } 4 \text { : Not Applicable } \\
\text { Module } 5 \text { : Not applicable except BE data }\end{array}$ \\
\hline 79. & $\begin{array}{l}\text { Why it is prudent to conduct intermediate } \\
\text { stability studies along with accelerated and } \\
\text { long term stability studies? }\end{array}$ & $\begin{array}{l}\text { In case accelerated stability fails, intermediate stability data is } \\
\text { considered by FDA }\end{array}$ \\
\hline 80. & $\begin{array}{l}\text { Name the guidelines for "Bracketing and } \\
\text { Matrixing Designs for Stability Testing }\end{array}$ & ICH Guidelines (Q1D) \\
\hline 81. & What is US DMF? & $\begin{array}{l}\text { It is a submission that may be used to provide confidential } \\
\text { detailed information about API, Excipients, Packaging } \\
\text { materials under NDA/ANDA }\end{array}$ \\
\hline 82. & $\begin{array}{l}\text { How reference to a particular US DMF (Type } \\
2,3,4 \text { ) helps in filing NDA/ANDA applications }\end{array}$ & $\begin{array}{l}\text { The applicant can incorporate it in ANDA/NDA just by } \\
\text { reference }\end{array}$ \\
\hline
\end{tabular}




\begin{tabular}{|c|c|c|}
\hline 83. & $\begin{array}{l}\text { What is the object of pre-approval inspection } \\
\text { for approving ANDA }\end{array}$ & To verify cGMP Compliances \\
\hline 84. & SUPAC? & $\begin{array}{l}\text { It stands for Scale up and Post approval changes in product } \\
\text { under ANDA }\end{array}$ \\
\hline 85. & SUPAC IR? & $\begin{array}{l}\text { It stands for Scale up and Post approval changes in Immediate } \\
\text { Release products }\end{array}$ \\
\hline 86. & SUPAC MR? & $\begin{array}{l}\text { It stands for Scale up and Post approval changes in Modified } \\
\text { Release Products. }\end{array}$ \\
\hline 87. & $\begin{array}{l}\text { How ANDA filings are numbered in eCTD } \\
\text { format? If the same number is valid over the } \\
\text { lifecycle of the product? }\end{array}$ & $\begin{array}{l}\text { ANDA filings are numbered by assigning six digit numbers } \\
\text { (issued by FDA) prior to submission. Once activated, it } \\
\text { remains valid over the life cycle of the product. }\end{array}$ \\
\hline 88. & $\begin{array}{l}\text { What is meant by "Refuse to Receive" with } \\
\text { respect to ANDA filing }\end{array}$ & $\begin{array}{l}\text { It is a refusal to accept ANDA Application. This happens } \\
\text { when the file structure or its contents are highly deficits }\end{array}$ \\
\hline 89. & What are the objectives of Hatch-Waxman Act & $\begin{array}{l}\text { To facilitate the approval and marketing of generic drugs } \\
\text { without conducting detailed safety and clinical studies } \\
\text { To control drug prices by provoking competition with new } \\
\text { drugs }\end{array}$ \\
\hline 90. & What is Patent Certificate & $\begin{array}{l}\text { It's a self-certified document to state " The applicant has not } \\
\text { violated any patent corresponding to NDA listed Orange } \\
\text { Book" }\end{array}$ \\
\hline 91. & What is the aim of BE Studies in ANDA & $\begin{array}{l}\text { To establish that the rate and extent of absorption of the } \\
\text { generic drug against Reference Listed Drug specified by FDA }\end{array}$ \\
\hline 92. & $\begin{array}{l}\text { Explain historical development of ANDA } \\
\text { filings }\end{array}$ & $\begin{array}{l}\text { Prior to } 1978 \text {, generic drug applications were required to have } \\
\text { complete quality. safety and efficacy data } \\
\text { During } 1978 \text {,generic applications were required to have } \\
\text { complete quality }+ \text { published data on safety and efficacy } \\
\text { In } 1984 \text { generic applications were required to have complete } \\
\text { quality data }+ \text { safety and clinical data incorporated by } \\
\text { reference to the specific NDA }\end{array}$ \\
\hline 93. & $\begin{array}{l}\text { Explain the woes of ANDA Holder before Wax } \\
\text { Hatchman Act? }\end{array}$ & $\begin{array}{l}\text { Cumbersome regulatory procedures } \\
\text { High investment } \\
\text { Lengthy time for review and approval } \\
\text { High Production cost }\end{array}$ \\
\hline 94. & What is PARA(1) with respect to ANDA filing & No patent has been filed. ANDA can be filed immediately \\
\hline 95. & What is PARA(2)with respect to ANDA filing & Patent has expired ( ANDA can be filed immediately \\
\hline 96. & $\begin{array}{l}\text { Explain the PARA (3) with respect to ANDA } \\
\text { filing }\end{array}$ & Patent is near to expiry. ANDA can be filed in advance \\
\hline 97. & What is PARA(4) with respect to ANDA filing & $\begin{array}{l}\text { Patent is invalid or irrelevant. ANDA can be filed any time } \\
\text { prior to its expiry }\end{array}$ \\
\hline 98. & Why ANDA filing under Para 4 is often risky? & $\begin{array}{l}\text { This Para often involves Litigations/law suits from the } \\
\text { Patent Holder }\end{array}$ \\
\hline 99. & $\begin{array}{l}\text { State the time allowed to NDA holder to } \\
\text { respond to challenge petition filed by a } \\
\text { prospective ANDA applicant under Para } 4 \text { ? }\end{array}$ & 45 days \\
\hline 100. & $\begin{array}{l}\text { State the market exclusivity provided to the } \\
\text { NDA holder under Para (iv) }\end{array}$ & 30 months \\
\hline
\end{tabular}

\section{Conclusion}

The article provides prominent facts on ANDA filings and general queries about ANDA, aspects like drafting, submission, review, and approval of ANDA are the major questions that are generally asked during the Regulatory Affairs Interview from Pharma companies. It is an excellent database for those seeking appointment in large pharmaceutical companies

\section{Acknowledgements}

The author is very much thankful to International Journal of Drug Regulatory Affairs for publishing the article.
Financial Disclosure statement: The author received no specific funding for this work.

\section{Conflict of Interest}

The author declares that there is no conflict of interest regarding the publication of this article.

\section{References}

1. ANDA Forms and Submission Requirements [Internet]. US FDA; 2019 [cited 2021 Jan 11]. Available from: https://www.fda.gov/drugs/abbreviated-new-drugapplication-anda/abbreviated-new-drug-application-andaforms-and-submission-requirements

2. Approved Drug Products with Therapeutic Equivalence Evaluations (Orange Book) [Internet]. U.S FDA; 2018 
May 17 [cited 2021 Jan 10]. Available from: https://www.fda.gov/drugs/developmentapprovalprocess/h owdrugsaredevelopedandapproved/approvalapplications/a bbreviatednewdrugapplicationandagenerics/default.htm

3. Quality by Design for ANDAs: An Example for Immediate-Release Dosage Forms [Internet]. US FDA; 2012 Apr [cited 2021 Jan 13]. Available from: https://www.fda.gov/media/83664/download

4. Determining Whether to Submit an ANDA or a 505(b)(2) Application [Internet]. US FDA; 2019 [cited 2021 Jan 12]. Available from: https://www.fda.gov/regulatory-information/search-fdaguidance-documents/determining-whether-submit-andaor-505b2-application

5. Question-Based Review for CMC Evaluations of ANDAs [Internet]. US FDA; 2019 Nov 11 [cited 2021 Jan 19]. Available from: https://www.fda.gov/drugs/abbreviated-new-drugapplication-anda/question-based-review-cmc-evaluationsandas

6. Generic Drug User Fee Amendments [Internet]. US FDA; $2021 \mathrm{Feb} 10$ [cited 2021 Jan 19]. Available from: https://www.fda.gov/industry/fda-user-feeprograms/generic-drug-user-fee-amendments

7. Abbreviated New Drug Application (ANDA) [Internet]. US FDA; 2019 May 22 [cited 2021 Jan 19]. Available from: https://www.fda.gov/drugs/typesapplications/abbreviated-new-drug-application-anda

8. Abbreviated New Drug Application (ANDA) and Prior Approval Supplement (PAS) Fees [Internet]. US FDA; 2017 Jan 19 [cited 2021 Jan 11]. Available from: https://www.fda.gov/industry/generic-drug-user-feeamendments/abbreviated-new-drug-application-anda-andprior-approval-supplement-pas-fees

9. ANDA Submissions -Content and Format Guidance for Industry [Internet]. US FDA; 2019 Jun [cited 2021 Jan 19]. Available from: https://www.fda.gov/regulatory-information/search-fdaguidance-documents/anda-submissions-content-andformat-abbreviated-new-drug-applications

10. Field Alert Reports [Internet]. US FDA; 2018 Jul [cited 2021 Jan 13]. Available from: https://www.fda.gov/drugs/surveillance/field-alert-reports

11. Pre-ANDA Program \& Complex Generic Products [Internet]. US FDA; 2017 Oct 27 [cited 2021 Jan 13]. Available from:

https://www.fda.gov/industry/generic-drug-user-feeamendments/pre-anda-program-complex-generic-products

12. ANDA Submissions - Refuse-to-Receive Standards Guidance for Industry [Internet]. US FDA; 2016 Dec [cited 2021 Jan 12]. Available from: https://www.fda.gov/media/86660/download

13. ANDAs: Stability Testing of Drug Substances and Products: Questions and Answers [Internet]. US FDA; 2014 May [cited 2021 Jan 12]. Available from: https://www.fda.gov/regulatory-information/search-fdaguidance-documents/andas-stability-testing-drugsubstances-and-products-questions-and-answers

14. ANDAs: Impurities in Drug Substances [Internet]. US FDA; 2020 Apr 04 [cited 2021 Jan 12]. Available from: https://www.fda.gov/regulatory-information/search-fdaguidance-documents/andas-impurities-drug-substances

15. Good ANDA Submission Practices Guidance for Industry [Internet]. US FDA; 2018 Jan [cited 2021 Jan 12]. Available from: https://www.fda.gov/regulatory-information/search-fdaguidance-documents/good-anda-submission-practicesguidance-industry
16. Shah S, Badjatya JK. Preliminary requirement for filing application in US. Int J Drug Reg Affairs [Internet]. 2018 Dec 20 [cited 2021 Jun 15];6(4):1-8. Available from: http://ijdra.com/index.php/journal/article/view/276

17. M SK, Katamreddy JD, P JR. A review on ANDA submission requirements for Generic drugs: "Paragraph IV certification" as per FDA CDER guidelines. Int J Drug Reg Affairs [Internet]. 2018 Sep 15 [cited 2021 Jun 15];6(3):5-12. Available from: http://ijdra.com/index.php/journal/article/view/260 